\title{
Survey of Some Lepidopterous Species Attracted to Light Traps in the Middle of Al-Jabal Al-Akhdar Region, Libya
}

\author{
Youssef M. Zayeid; Othman B. H. Aldaikh and Soha A. Bomadas ${ }^{1}$
}

\begin{abstract}
The current study was carried out to identity 18 species of order lepidoptera belonging to 17 genera, 10 subfamilies and 6 families from Al-Jabal Al-AKhdar, Libya.The survey of these species were conducted in 12 regions during the period from January to December 2018, The percentage of the presence of each species in the studied regions has been determined. The species global distribution, synonyms, common names and hosts plant also were given.
\end{abstract}

Keyword: Lepidoptera, Light traps, Al-Jabal AlAKhdar, Libya, Species, Survey.

\section{INTRODUCTION}

The order Lepidoptera comprises the moths and butterflies, is one of the largest insect order, with 175,000 species represented in 128 families and 47 super families worldwide (Kristensen and Skalski 1999). The members of this order are surprisingly alike with respect to their food source, nearly all of which are green plant feeders. The great majority of larvae chew up leaves, many pore tunnel inside leaves, some bore into stone fruits and seeds while others visit flowers for nectar (ACSAD, 1981). More than 19 species have been reported for the frist time in Libya, Al-Jabal Al-AKhdar area, at El-kof National park (Zavattari, 1934).

Lepidoptera is one of the most common economically, important and wide spread orderes of the insects, while moths represent one of the most heterogeneous groups (Devoto et .al, 2011 and Le Croy et .al, 2013). The study on some Lepidoptera species by El-Megrhabi (2001) suggested 26 species, 15 of these reported for the first time in Benghazi Libya. In this paper additional information about Lepidopteron fauna of Al-Jabal Al-AKhdar, Libya was given.

\section{MATERIALS AND METHODS}

A survey of Lepidoptera order was conducted in North, Southern, Eastern and Western El-Bieda, AlJabal Al-Akdar region. As all survey area were located in Al-Jabal Al-Akhdar (Massah, Sidi Abdel Wahed, Omar al-Mukhtar, Al-Abraq, Qarnada, Al- faidia, Al- wasita, Al-haniya, Al-hamama, Shahat, Al - Mansoura and Susa), they all experienced similar climatic conditions of precipitin humidity and temperature. The study represented sea- levels rise scales ranged from 20 to $500 \mathrm{~m}$.

From January to December 2018 samples were collected from the forementioned regions using light traps and white sheet reflects light and acts as structure for insect to land on from different plant, (forest and fruits trees as well as several crops and weeds).

In this paper taxonomic notes, Terminology and abbreviation are provided according to several authors (Wiltshire, 1948; Karsholt and Razowski, 1996; Heppner, 1998; Scudder and Cannings, 2007; and Bader, 2014). Specimens were deposited in Entomology museum collection, plant protection department. Faculty of Agriculture, Omar Al-Mukthar University.

\section{RESULTS}

The data in Table (1) show the species that were collected in the study, along with the families to which they belong and sub families, as well as the global distribution, synonyms, common names and hosts plants. The current study showed 18 species belonging to 17 genera, 10 subfamilies and 6 families.

Table (2) shows the species that were recorded and also the number of specimens collected to all species in the study regions, where Massah region recorded the highest number of 165 specimens, while the lowest number of specimens was recorded in Susa region (126), the most dominant species in the study regions, Tuta absoluta (246 speacimens), while the least in number was (43 speacimens) Acherontia atropos.

\section{DISCUSSION}

Field survey was conducted during the period of 2018 in twelve regions in the middle of Al- Jabal Alkhdar they were Massah, Sidi Abdel Wahed, Omar al-Mukhtar, Al-Abraq, Qarnada, Al- Fadia, Alwasita, Al-haniya, Al-hamama, Shahat, Al-Mansoura and Susa.

The data obtained in the study indicated that the greatest family found in the study area, the highest

\footnotetext{
DOI: 10.21608/asejaiqjsae.2021.177466

${ }^{1}$ Department of Plant Protection, College of Agriculture,

University Omar Al-Mukhtar, Libya

ymaied@yahoo.com

Othman.aldaikh@gmail.com

Suha520@gmail.com

Received May 4, 2021, Accepted, June 13, 2021.
} 
number of recorded species was family Sphingidae with eight species, and six species from family noctuidae while one species from each of Cossidae; Torticidae; Gelechiidae and Artciidae. Several authors throughout the world have been studied and discussed the various aspects of the order Lepidoptera, In Libya, fragmentary and often incomplete studies were made on this order there has been only one extensive Libyan faunal work on all orders of insects including order Lepidoptera by Zavattira (1934) and Damiano (1961). In addition Kemal and Kocak (2007) gave detailed account on some families belong to order Lepidoptera at North Africa including Libya. General survey carried out by revising the main reference on Lepidoptera in Libya by Turati and Kruger (1936); ACSAD (1981); Amin et.al. (1998);
El-Meghrabi (2001); El-Meghrabi and Amin (2007). as well as Mohamed and Shaurub (2010).

Many of the established species in the Libyan fauna were firstly introduced to the country with several exported crops such as vegitables and fruits. It seems from our survey that the important species (about 21 species). Gelehiidae is one of the most important families under study although only one species was recorded (Tuta absoluta) but considered one of the most serious pests on tomato plant. It was recorded in Libya 2009 (Moussa et al. 2013 and Salama et al. 2015). Utilization of insecticides and quarantine measures are strongly requested to prevent any new aphids introduced to Libya.

\section{Table 1. The species that the study regions, were collected and some data related to them.}

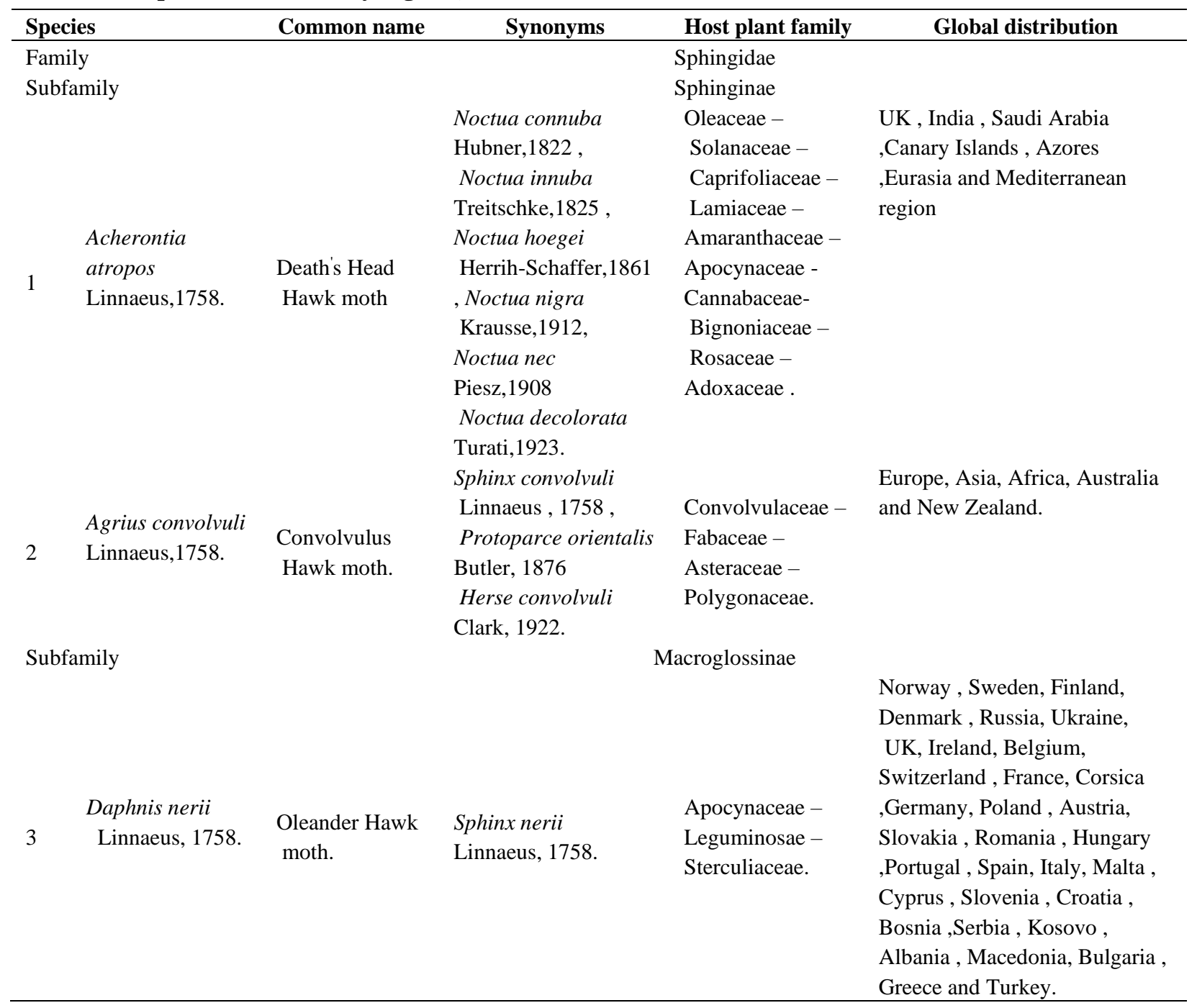


Cont. Table 1. The species that the study regions, were collected and some data related to them.

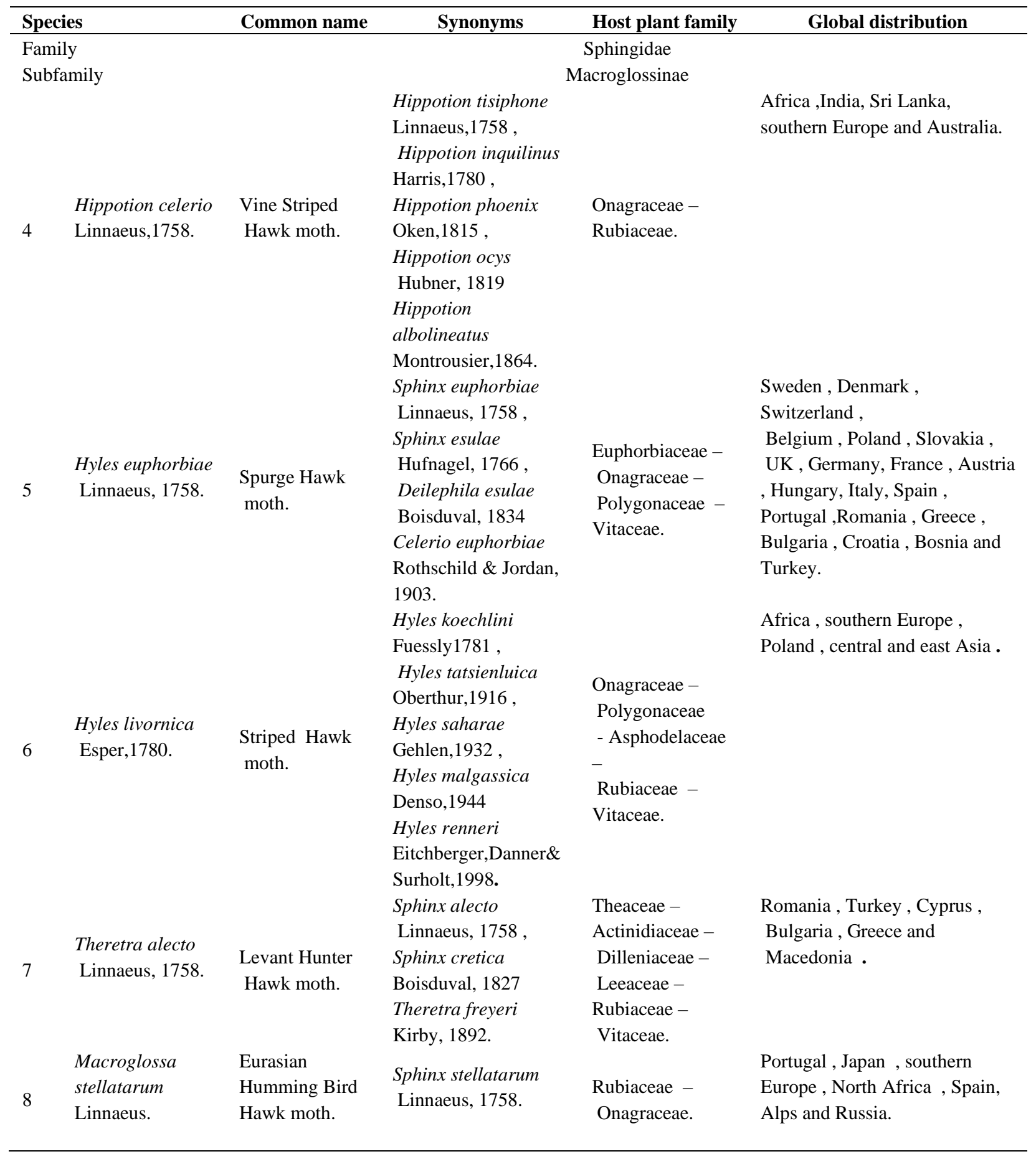


Cont. Table 1. The species that the study regions, were collected and some data related to them.

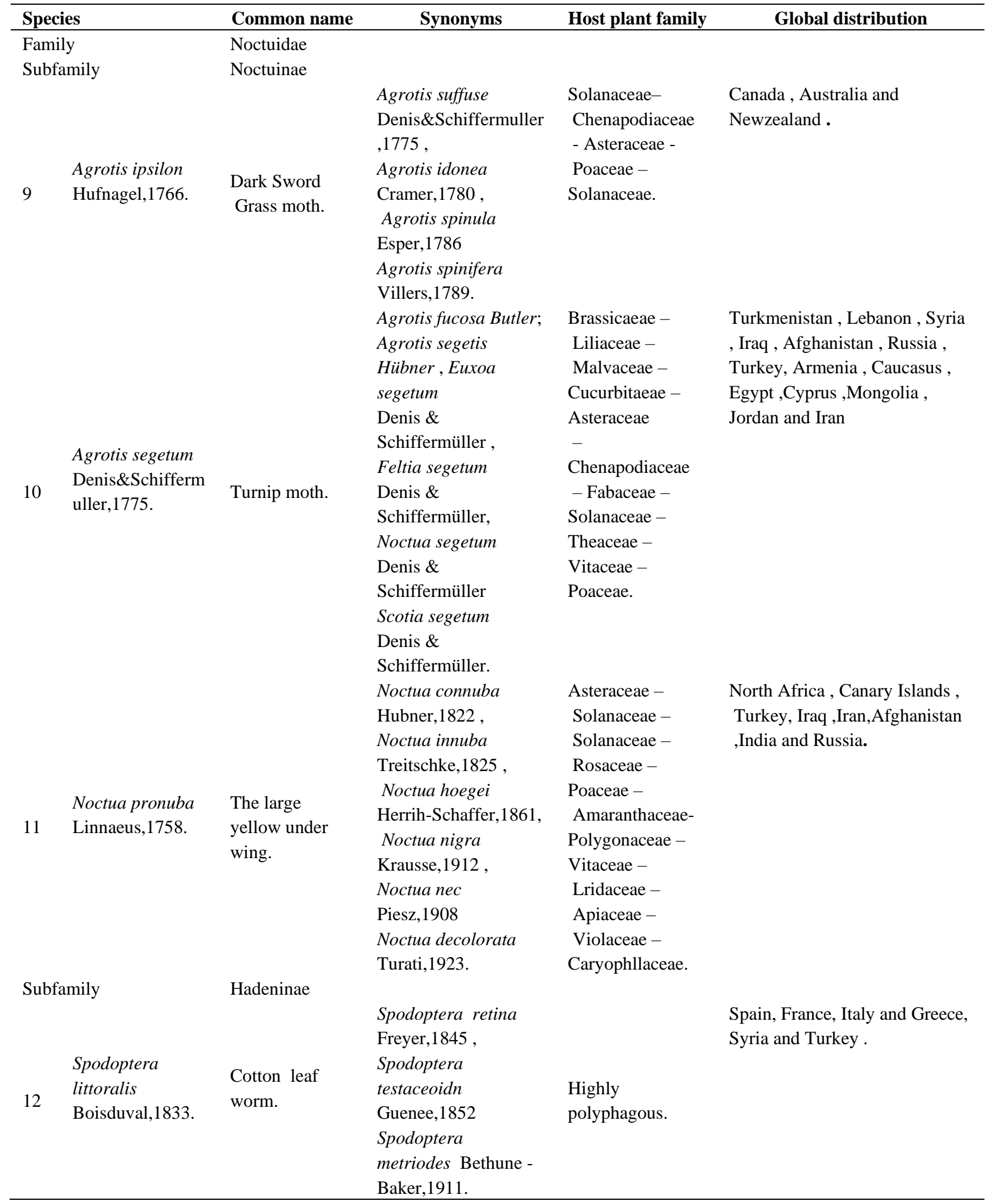


Cont. Table 1. The species that the study regions, were collected and some data related to them.

\begin{tabular}{|c|c|c|c|c|c|}
\hline \multicolumn{2}{|c|}{ Species } & Common name & Synonyms & Host plant family & Global distribution \\
\hline \multicolumn{2}{|c|}{ Family } & Noctuidae & & & \\
\hline \multicolumn{2}{|c|}{ Subfamily } & Plusiinae & & & \\
\hline 13 & $\begin{array}{l}\text { Autographa } \\
\text { gamma } \\
\text { Linnaeus, } 1758 .\end{array}$ & silver Y moth. & $\begin{array}{l}\text { Phalaena gamma } \\
\text { Linnaeus, } 1758, \\
\text { Autographa } \\
\text { messmeri } \\
\text { Linnaeus, } 1758, \\
\text { Autographa volkeri } \\
\text { Linnaeus, } 1758 .\end{array}$ & $\begin{array}{l}\text { Solanaceae - } \\
\text { Oleraceae - } \\
\text { Brassicaeae - } \\
\text { Fabaceae - } \\
\text { Chenapodiaceae - } \\
\text { Linaceae. }\end{array}$ & $\begin{array}{l}\text { North Africa_Iceland, } \\
\text { Greenland,and Finland }\end{array}$ \\
\hline \multicolumn{2}{|c|}{ Subfamily } & Catocalinae & & & \\
\hline 14 & $\begin{array}{l}\text { Dysgonia torrida } \\
\text { Guenée, } 1852 .\end{array}$ & The Jigsaw. & $\begin{array}{l}\text { Bastilla torrida, } \\
\text { Ophiusa albivitta, } \\
\text { Ophiusa festina, } \\
\text { Ophiusa torrida } \\
\text { Guenée, } 1852 \\
\text { Parallelia torrida. }\end{array}$ & $\begin{array}{l}\text { Poaceae - } \\
\text { Euphorbiaeae- } \\
\text { Leguminasae- } \\
\text { Salicaceae }\end{array}$ & $\begin{array}{l}\text { Spain, Italy, Greece, Syria, Iran, } \\
\text { Uzbekistan, India, SriLanka and } \\
\text { Myanmar. }\end{array}$ \\
\hline Subfamily & ly & $\begin{array}{l}\text { Cossidae } \\
\text { Zeuzerinae }\end{array}$ & & & \\
\hline 15 & $\begin{array}{l}\text { Zeuzera pyrina } \\
\text { Linnaeus, } 1761 .\end{array}$ & Leopard moth. & $\begin{array}{l}\text { Zeuzera hypocastani } \\
\text { Poda,1761, } \\
\text { Zeuzera aesuli } \\
\text { Linnaeus, } 1767, \\
\text { Zeuzera hilaris } \\
\text { Foureroy,1832. }\end{array}$ & $\begin{array}{l}\text { Caprifoliaceae - } \\
\text { Fabaceae- } \\
\text { Oleaceae - } \\
\text { Rosaceae - } \\
\text { Fagaceae - } \\
\text { Moraceae - } \\
\text { Ulmaceae - } \\
\text { Ericaceae- } \\
\text { Sapindaceae. }\end{array}$ & $\begin{array}{l}\text { Algeria ,Egypt, Libya, } \\
\text { Morocco,Taiwan , India, Iraq, } \\
\text { Japan ,Korea ,Lebanon , Sri } \\
\text { Lank , Syria and Turkey. }\end{array}$ \\
\hline Family & & Arctiidae & & & \\
\hline \multicolumn{2}{|c|}{ Subfamily } & Arctiinae & & & \\
\hline 16 & $\begin{array}{l}\text { Ocnogyna loewii } \\
\text { Zeller, } 1846 .\end{array}$ & $\begin{array}{l}\text { Spring } \\
\text { Webworm. }\end{array}$ & $\begin{array}{l}\text { Trichosoma loewii } \\
\text { Zeller, } 1846 \\
\text { Ocnogyna clathrata } \\
\text { Leader, } 1855 .\end{array}$ & $\begin{array}{l}\text { Asteraceae - } \\
\text { Fabaceae. }\end{array}$ & $\begin{array}{l}\text { Egypt, Greece, Uzbekistan, } \\
\text { Afghanistan, Iraq andRussia. }\end{array}$ \\
\hline \multicolumn{2}{|c|}{ Family } & $\begin{array}{l}\text { Tortricidae } \\
\text { Olethreutinae }\end{array}$ & & & \\
\hline 17 & $\begin{array}{l}\text { Cydia pomonella } \\
\text { Linnaeus, } 1758 .\end{array}$ & Codling moth & $\begin{array}{l}\text { Phalaena pomonella } \\
\text { Linnaeus, } 1758, \\
\text { Phalaena tortrix } \\
\text { Villers, } 1789, \\
\text { Carpocapsa } \\
\text { splendana Rebel, 1; } \\
\text { Pyralis pomana } \\
\text { Fabricius, } 1775 \\
\text { Tortrix pomonana } \\
\text { Denis \& } \\
\text { Schiffermuller, } 1775 .\end{array}$ & $\begin{array}{l}\text { Rosaceae - } \\
\text { Juglandaceae- } \\
\text { Magnolioideae. }\end{array}$ & $\begin{array}{l}\text { Australia , Newzealnd, } \\
\text { Kazakhstan ,Japan , Brazil, } \\
\text { Russia, south Africa,India, } \\
\text { China ,USA and Canada. }\end{array}$ \\
\hline
\end{tabular}


Cont. Table 1. The species that the study regions, were collected and some data related to them.

\begin{tabular}{|c|c|c|c|c|}
\hline Species & Common name & Synonyms & Host plant family & Global distribution \\
\hline Family & Gelechiidae & & & \\
\hline Subfamily & Gelechiinae & & & \\
\hline $\begin{array}{l}\text { Tuta absoluta } \\
\text { Meyrick, } 1917 .\end{array}$ & $\begin{array}{l}\text { Tomato Leaf } \\
\text { miner. }\end{array}$ & $\begin{array}{l}\text { Scrobipalpuloides } \\
\text { absoluta Povolny, } \\
\text { 1987, Scrobipalpula } \\
\text { absoluta Povolny, } \\
\text { 1964; Becker, 1984, } \\
\text { Gnorimoschema } \\
\text { absoluta Clarke, } 1962 \\
\text { Phthorimaea absoluta } \\
\text { Meyrick, } 1917 .\end{array}$ & $\begin{array}{l}\text { Solanaceae - } \\
\text { Fabaceae. }\end{array}$ & $\begin{array}{l}\text { Spain , Morocco, Tunisia, } \\
\text { France, Italy, Canary Islands, } \\
\text { Algeria, Albania , Bulgaria , } \\
\text { Netherlands , Portugal , U K, } \\
\text { Hungary , Turkey, Serbia, } \\
\text { Sudan, Ethiopia , Niger and } \\
\text { Senegal. }\end{array}$ \\
\hline
\end{tabular}

Table 2. Number of the species that were recorded in the study regions.

\begin{tabular}{|c|c|c|c|c|c|c|c|c|c|c|c|c|c|c|}
\hline & \multirow[b]{2}{*}{ Species } & \multicolumn{13}{|c|}{ Study regions } \\
\hline & & 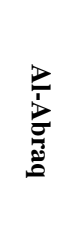 & 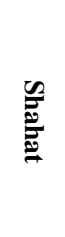 & 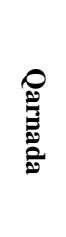 & 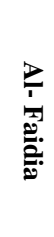 & 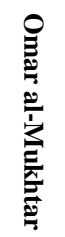 & $\begin{array}{l}3 \\
3 \\
0 \\
0\end{array}$ & 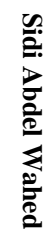 & $\begin{array}{l}\mathscr{E} \\
\tilde{D}\end{array}$ & 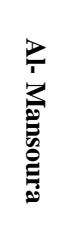 & 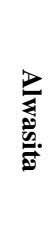 & $\underset{D}{\stackrel{1}{ت}}$ & 芒 & 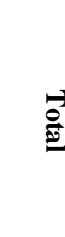 \\
\hline 1 & Acherontia atropos & 4 & 6 & 3 & 5 & 2 & 3 & 4 & 2 & 5 & 4 & 2 & 3 & 43 \\
\hline 2 & Agrius convolvuli & 6 & 2 & 5 & 4 & 2 & 7 & 5 & 3 & 4 & 6 & 3 & 5 & 52 \\
\hline 3 & Daphnis nerii & 4 & 5 & 4 & 6 & 5 & 5 & 6 & 3 & 4 & 6 & 4 & 3 & 55 \\
\hline 4 & Hippoton celerio & 7 & 4 & 6 & 3 & 6 & 8 & 4 & 6 & 6 & 7 & 5 & 4 & 66 \\
\hline 5 & Hyles euphorblae & 3 & 5 & 6 & 5 & 4 & 3 & 。 & 4 & 3 & 6 & 3 & 2 & 49 \\
\hline 6 & Hyles livornica & 8 & 6 & 4 & 7 & 5 & 9 & 6 & 5 & 5 & 7 & 4 & 5 & 71 \\
\hline 7 & Macroglossum stellatarum & 5 & 6 & 6 & 4 & 6 & 7 & 5 & 4 & 5 & 6 & 5 & 5 & 64 \\
\hline 8 & Theretra alecto & 7 & 4 & 3 & 5 & 6 & 5 & 3 & 5 & 4 & 6 & 5 & 4 & 57 \\
\hline 9 & Agrotis ipsilon & 18 & 14 & 17 & 11 & 12 & 21 & 15 & 16 & 13 & 17 & 14 & 9 & 177 \\
\hline 10 & Agrotis segetum & 15 & 17 & 22 & 18 & 16 & 14 & 16 & 17 & 15 & 19 & 18 & 14 & 201 \\
\hline 11 & Autographa gamma & 14 & 16 & 18 & 12 & 14 & 15 & 12 & 16 & 13 & 17 & 14 & 16 & 177 \\
\hline 12 & Dysgonia torrida & 7 & 5 & 10 & 6 & 8 & 12 & 4 & 6 & 9 & 6 & 5 & 7 & 85 \\
\hline 13 & Noctua pronuba & 20 & 13 & 9 & 17 & 11 & 12 & 14 & 15 & 10 & 16 & 19 & 18 & 174 \\
\hline 14 & Spodoptera littoralis & 17 & 23 & 19 & 16 & 20 & 18 & 15 & 12 & 21 & 14 & 17 & 19 & 211 \\
\hline 15 & Cydia pomonella & 11 & 10 & 9 & 12 & 11 & 14 & 8 & 10 & 13 & 11 & 9 & 12 & 130 \\
\hline 16 & Ocnogyna loewii & 13 & 9 & 8 & 10 & 7 & 12 & 11 & 9 & 12 & 11 & 8 & 7 & 117 \\
\hline 17 & Tuta absoluta & 23 & 19 & 21 & 22 & 18 & 24 & 25 & 19 & 20 & 26 & 20 & 23 & 260 \\
\hline 18 & Zeuzera pyrina & 10 & 12 & 10 & 11 & 9 & 8 & 8 & 9 & 6 & 9 & 11 & 12 & 115 \\
\hline Tota & & 202 & 176 & 180 & 174 & 162 & 197 & 176 & 161 & 168 & 194 & 166 & 168 & \\
\hline
\end{tabular}

Figure (1) shows the percentages of the speacimens recorded in each study regions, it is clean that the percentage was close to each other in all regions.
Figure (2) shows the percentages of the families recorded in the study regions, The highest percentage of Sphingidae and Noctuidae was $44 \%$ and $33 \%$, respectively, and the lowest percentage of Cossidae was $5 \%$. 


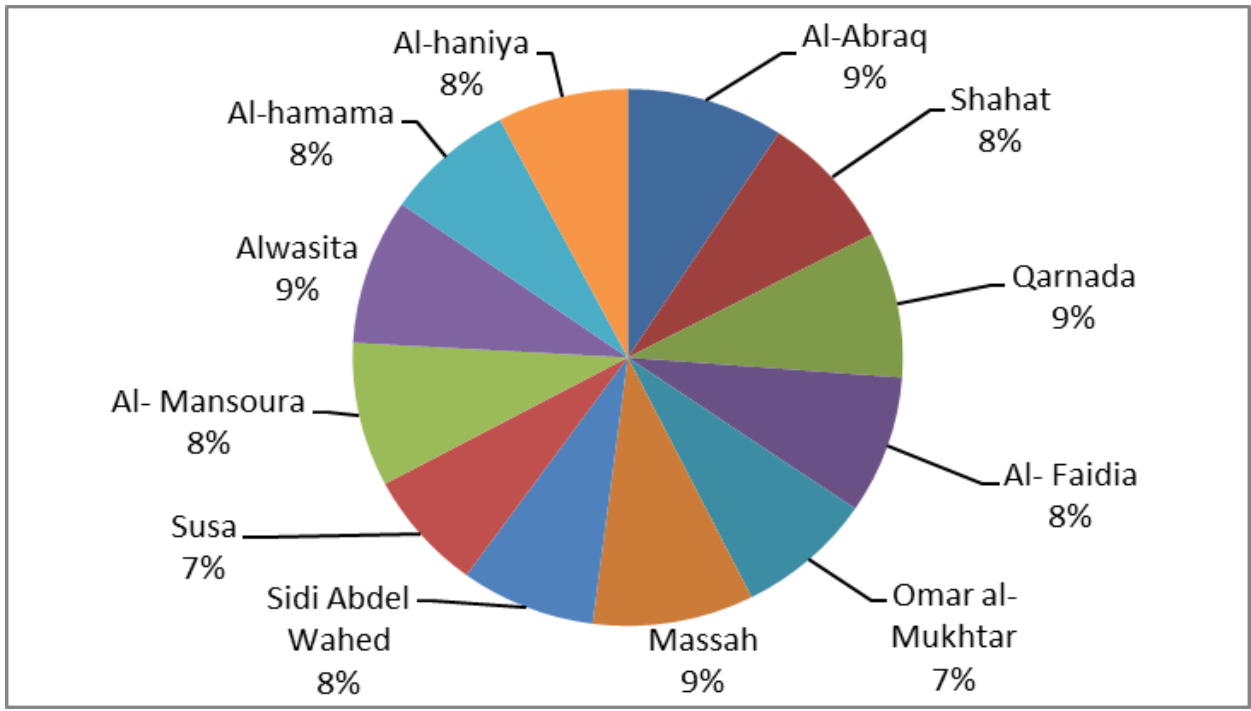

Figure 1. The percentage of abundance in the study regions.

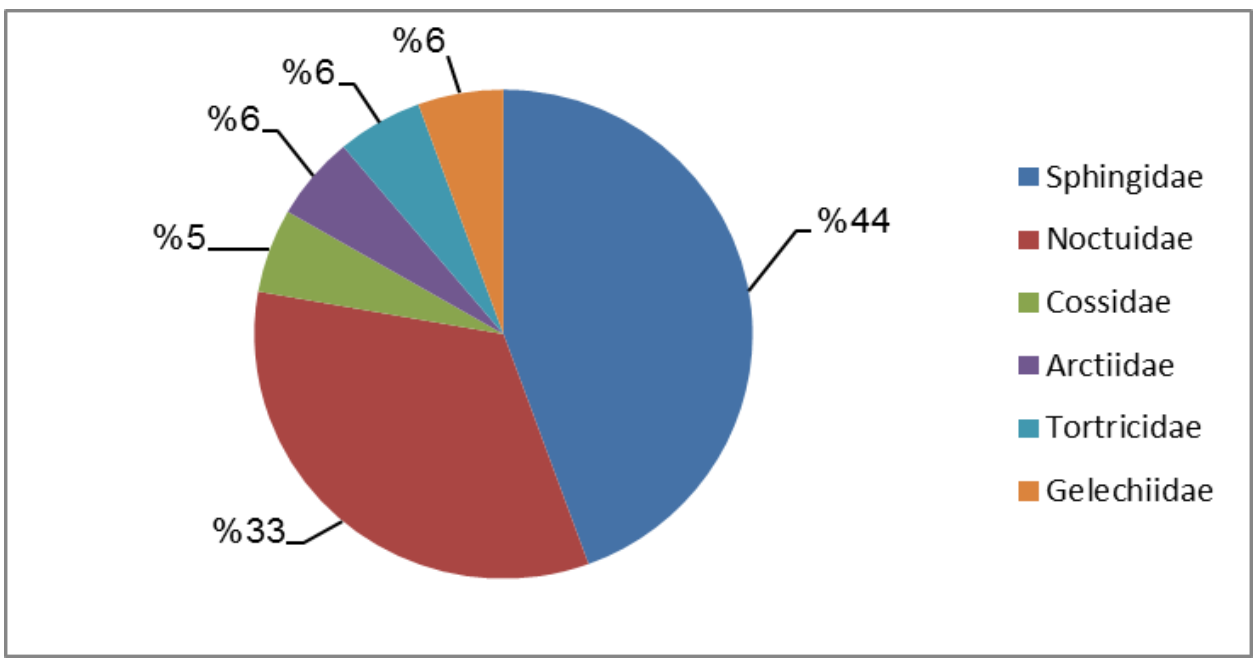

Figure 2. The percentage of families in the study regions.

\section{REFERENCES}

ACSAD. 1981. Studies project Kuf National Park (The study insects) Arab centre for the studies of Arid Zones and Dry Lands., pp: 199.

Amin, A.H., A.A. Bataw and I.M. El-Ghariani. 1998. A preliminary study of insects associated with some weeds in El-Beida region in Libya. Mukhtar J. of Sciences., 5: 143-150.

Bader, K. A. 2014. Contribution to the Hawk Moths (Sphingidae: Lepidoptera) of Jorden. J. of Natural History. Vol.1: 59-82 .
Damiano, N.A. 1961. Elencodella specie di insettidannosiricordati per la Libia fino al 1960. Tipografia del governo, Nazirato dell Agricoltur.Tripoli, pp.27- 81.

Devoto, M., S. Bailey and J. Memmott. 2011. The night shift: nocturnal pollen-transport networks in a boreal pine forest. Ecological Entomology; 36: 25-35.

El-Meghrabi, M. S. 2001. List of the Lepidoptera insects captured in Benghazi area, their world distribution, host plants, and notes on taxonomy. Journal of Arts and Science., 6:336 - 349 .

El-Meghrabi, M.S. and A.H. Amin. 2007. List of the Lepidoptera insects surveyed in El- Beida area, with their world distribution, host plants, and notes on taxonomy. J. of Science and Application, 1(2): 21-31. 
Heppner, J.B. 1998. Classification of Lepidoptera. Part 1. Introduction. Holarctic Lepidoptera, 5 (Suppl. 1): 1-148.

Kemal, M. and A.O. Kocak. 2007. Second report on the temporary results of the Lepidoptera list of Africa continent based upon the info system of the Cesa. Royel Museum for Central Africa, pp: 21.

Karsholt, O. and J. Razowski. 1996. The Lepidoptera of Europe., Apollo Books, Stenstrup. 380 pp.

Kristensen, N. P. and A.W. Skalski. 1999. Phylogeny and paleontology. Pages 725 in: Lepidoptera: Moths

and Butterflies. 1. Evolution, Systematics, and Biogeography. Handbook of Zoology Vol. IV, Part 35. N. P. Kristensen, ed. De Gruyter, Berlin and New York.

Le Croy, K.A., H.W. Shew and P.A. Van Zandt. 2013. Pollen presence on nocturnal moths in the Ketona

Dolomite glades of Bibb County, Alabama. Southern Lepidopterists News; 35: 136-142.

Mohamed,W.F and E.H. Shaurub. 2010. A checklist of some recorded insects in Misurata, Libya. J. of King Saud University (Science)., 22: 61-65.
Moussa, S., A. Sharma, F. Baiomy and F.E. El-Adl. 2013. The status of tomato leaf miner Tuta absoluta (Meyrick) (Lepidoptera: Gelechiidae) in Egypt and potential effective pesticides. Academic J. of Entomology. 6: 110115.

Salama, H.S.A., I.A. Ismail, M. Fouda, I. Ebadah and I. Shehata. 2015. Some Ecological and Behavioural Aspects of the Tomato Leaf Miner Tuta absoluta (Meyrick) (Lepidoptera: Gelechiidae). J. of Balkan Ecology .7: 3544.

Scudder, G.G.E. and R.A.Cannings. 2007. The Lepidoptera Families and Associated Orders of British Columbia, 160: pp.

Turati, E and G. Kruger. 1936. Contributi Alia Fauna Cirenaica. Novitä Di Lepidoptterologia. Mem.Soc.Ent.Ital., 15: 55-77.

Wiltshire, E. P. 1948. The Lepidoptera of the Kingdom of Egypt., Bull. Soc. Fouad. Ent., 32: 203-294.

Zavattari, E. 1934. Prodromodella fauna della libya.Tipografagia cooperative, pavia, pp: V1ll+1234.

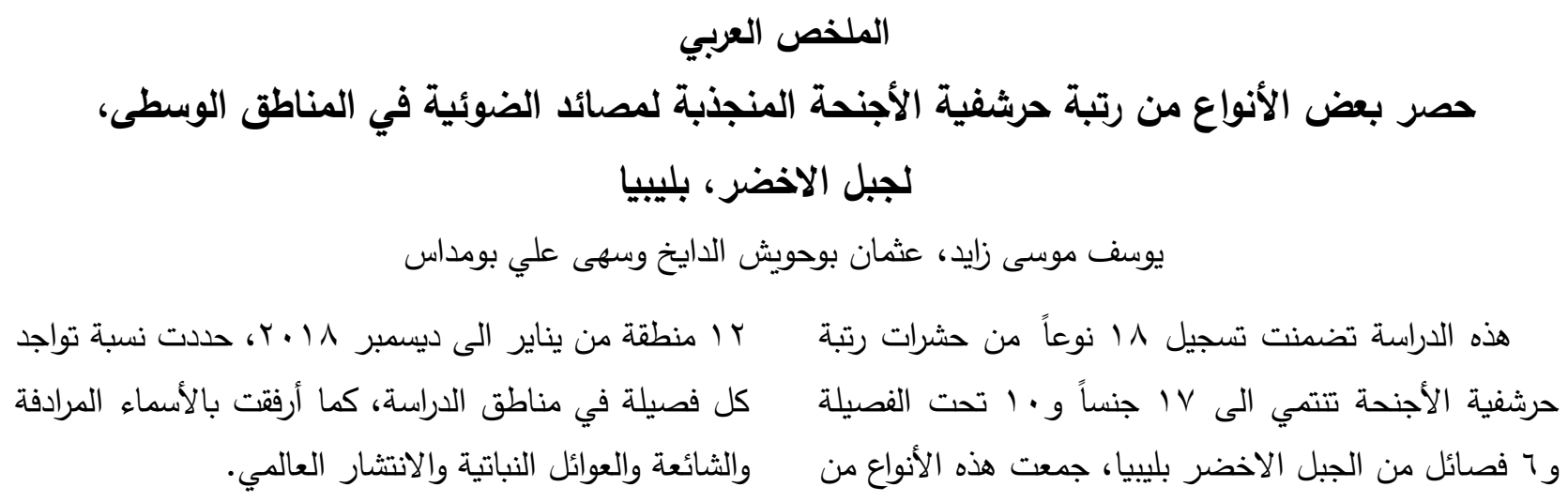

